\title{
Analisis Spasial Kejadian Diare dengan Keberadaan Sumur Gali di Kelurahan Jabungan Kota Semarang
}

\author{
Hanan Lanang Dangiran ${ }^{1 *}$, Yudhy Dharmawan ${ }^{1}$ \\ ${ }^{1}$ Fakultas Kesehatan Masyarakat Universitas Diponegoro Semarang \\ * Corresponding Author: hanandangiran@gmail.com
}

Info Artikel : Diterima 22 Oktober 2019 ; Disetujui 7 Februari 2020 ; Publikasi 1 April 2020

\begin{abstract}
ABSTRAK
Latar belakang: Sumur gali adalah salah satu sarana penyedia air bersih yang digunakan oleh masyarakat Kelurahan Jabungan. Dari 31 sumur, terdapat 16 warga yang menggunakan untuk keperluan air minum. Pada tahun 2017 dilakukan pemeriksaan kualitas total coliform air sumur pada 3 sampel dengan hasil masing-masing $>300 \mathrm{CFU} / 100 \mathrm{ml}$ yang menunjukkan bahwa sampel tersebut tidak layak untuk digunakan sebagai air bersih dan air minum. Penelitian ini bertujuan menganalisis secara spasial kejadian diare dengan keberadaan sumur gali di Kelurahan Jabungan Kota Semarang.

Metode: Jenis penelitian ini adalah observasional dengan populasi yaitu seluruh sumur gali dan masyarakat yang terkena diare yang berjumlah 31 sumur dan 20 warga. Penentuan jumlah sampel menggunakan metode total sampling. Data diperoleh dari hasil survei, pengukuran dan sampling yang kemudian dianalisis secara spasial dengan pendekatan overlay.

Hasil: Dalam penelitian ini didapatkan hasil yaitu terdapat $87,1 \%$ sumur dengan total coliform $>50 \mathrm{CFU} / 100 \mathrm{ml}$, $87,1 \%$ sumur yang jarak dengan jamban $<11$ meter dan $87,1 \%$ sumur yang berjarak dengan septictank $<11$ meter. Hasil analisis overlay menunjukkan adanya keterkaitan antara kejadian diare dengan kondisi bakteriologis sumue gai dan jarak sumur gali dengan sumber pencemar, dimana kondisi sumur gali yang kualitas bakteriologis dan jaraknya dengan sumber pencemar tidak memenuhi syarat maka dapat meningkatkan peluang terjadinya kasus diare di rumah dengan kondisi sumur gali tersebut.

Simpulan: Penelitian ini menyimpulkan bahwa sebaran kejadian diare di Kelurahan Jabungan banyak ditemukan pada rumah yang memiliki sumur gali dengan kualitas bakteriologis air yang tidak memenuhi persyaratan yaitu $>50 \mathrm{CFU} / 100 \mathrm{ml}$ sampel dan jarak dengan jamban dan/atau septictank $<11$ meter.
\end{abstract}

Kata kunci: Diare; Sumur Gali; Kelurahan Jabungan

\section{ABSTRACT}

Title: Spatial Analysis of Diarrhea with Quality of Well Water in Jabungan, Semarang City

Background: Dug wells are one of the clean water supply facilities used by the Jabungan Sub-district community. Of the 31 wells, 16 residents are needed to use it for drinking water. In 2017 an examination of total well water quality in 3 samples with results of $>300 C F U / 100 \mathrm{ml}$ each indicated that the samples were not suitable for use as clean water and drinking water. This study discusses the spatial analysis of diarrhea events by digging wells in Jabungan Sub-district, Semarang.

Methods: This type of research is observational with a population of all wells and people who spend diarrhea that requires 31 wells and 20 residents. Determination of the number of samples using the total sampling method. Data obtained from the results of surveys, measurements and sampling are then spatially analyzed by obtaining overlays.

Results: In this study the results obtained were about $87.1 \%$ of wells with a total coliform $>50 \mathrm{CFU} / 100 \mathrm{ml}$, $87.1 \%$ of wells with a distance of $<11$ meters and $87.1 \%$ of wells needed with septic tank $<11$ meters. The results of the overlay analysis show a link between the incidence of diarrhea with the bacteriological condition of the sumai and the distance of the dug well to the source of the pollutant, where the condition of the dug well with bacteriological quality and the distance from the source of the pollutant are needed to ensure this. 
Conclusion: This study concludes that the distribution of diarrhea in Jabungan Sub-district is found in homes that have dug wells with water bacteriological quality that do not meet the requirements of $>50 \mathrm{CFU} / 100 \mathrm{ml}$ sample and distance from latrines and / or septic tank $<11$ meters.

Keywords: Diarrhea; Well Dug; Jabungan Sub-district

\section{PENDAHULUAN}

Diare adalah gangguan dalam Buang Air Besar (BAB) yang ditandai dengan $\mathrm{BAB}$ lebih dari tiga kali sehari dengan konsistensi tinja cair, dapat disertai dengan darah dan atau lendir. ${ }^{1}$ Indonesia merupakan salah satu negara berkembang yang bermasalah dengan penyakit diare karena morbiditas dan mortalitasnya yang masih tinggi. Kejadian iare jugaperlu diwaspadai karena merupakan penyakit yang berpotensi mengalami kejadian luar biasa (KLB) di Indonesia. Pada tahun 2015, terjadi 18 kali KLB diare di Indonesia yang tersebar di 18 kabupaten/ kota dengan angka kematian (CFR) mencapai 2,74\% sehingga dapat dikatakan sudah melebihi target CFR yang diharapkan yaitu $<1 \%{ }^{2}$

Berdasarkan SIMPUS dalam Profil Kesehatan Kota Semarang tahun 2018, penyakit diare menempati kelompok 10 besar penyakit yang banyak diderita masyarakat Kota Semarang. Penderita Diare dari tahun 2013 - 2016 cenderung mengalami penurunan namun naik di tahun 2017 dengan total kasus diare di tahun tersebut sebanyak 38.766 kasus. Menurut jenis kelamin, kasus diare di tahun 2017 tampak bahwa kasus diare pada perempuan 53\% lebih banyak dibanding pada laki - laki $47 \%{ }^{3}$

Faktor yang dapat mempermudah atau mempercepat terjadinya diare disebabkan oleh kuman, keadaan gizi, hygiene \& sanitasi, sosial budaya, kepadatan penduduk dan sosial ekonomi. Dinas Kesehatan Provinsi Jawa Tengah menyatakan bahwa diare merupakan salah satu penyakit berbasis lingkungan. Bila lingkungan tidak sehat (karena tercemar kuman diare) dan berakumulasi dengan perilaku manusia yang tidak sehat (melalui makanan dan minuman), maka akan mengakibatkan kejadian diare. $^{4}$

WHO memperkirakan bahwa penyebab utama kejadian diare di negara-negara berkembang adalah Rotavirus dan bakteri Escherichia coli. Kedua agen penyakit tersebut sangat erat hubungannya dengan faktor lingkungan seperti higiene sanitasi, kecukupan sarana air bersih dan air minum, serta kebersihan dan keamanan pangan. ${ }^{5}$

Air juga merupakan media penularan penyakit yang dapat menyebabkan menurunnya derajat kesehatan masyarakat. Pencemaran pada sarana air bersih mengakibatkan kualitas air bersih menjadi menurun baik dalam kualitas fisik dan biologisnya. Secara mikrobiologis air yang mengalami pencemaran di dalamnya terdapat bakteri coliform. Adapun mikroorganisme patogen dalam air yang lain yaitu protozoa, virus dan parasit.
Kehadiran bakteri coliform di air sumur dapat mengindikasikan kontaminasi oleh air tanah karena kotoran manusia atau kotoran hewan yang dapat mengandung bakteri, virus atau organisme penyebab penyakit lainnya. Beberapa penelitian menunjukkan bahwa mengkonsumsi air tercemar yang ditandai adanya coliform dapat meningkatkan risiko seorang terkena penyakit gastrointestinal akut atau penyakit pencernaan akut. Banyak sekali penyakit yang disebabkan oleh air yang kotor atau air yang tercemar. Salah satu penyakit yang disebabkan oleh air kotor atau tercemar yaitu diare.

Sarana penyedia air bersih yang biasa digunakan oleh masyarakat di pedesaan maupun di perkotaan saat ini adalah sumur gali. Sumur gali digunakan karena kemudahan dalam pembuatannya dan memerlukan biaya yang cukup murah serta merupakan air tanah yang dapat tersedia sepanjang tahun. ${ }^{6}$ Hasil dari Riset Kesehatan Dasar tahun 2018 di Indonesia penggunaan air bersih masyarakat bersumber dari PAM (41,96\%), air sumur bor/pompa $(15,42 \%)$, sumur gali terlindung (21\%), sumur gali tak terlindung $(6,04 \%)$, air permukaan $(1,5 \%)$ dan air hujan $(2,4 \%)^{(1)}$ Menurut Profil Kesehatan Kota Semarang Tahun 2018 sarana air bersih masyarakat terbagi atas sumur gali terlindung (12\%), sumur gali dengan pompa (5\%), sumur bor dengan pompa (7\%), dan sisanya perpipaan $(76 \%){ }^{3}$

Berdasarkan data dari Profil Puskemas Padangsari Tahun 2018, diketahui bahwa diare merupakan salah satu dari 10 besar penyakit yang terjadi di wilayah kerja Puskesmas. Dengan trend kasus mengalami kenaikan yaitu dari 50 kasus pada tahun 2016, 58 kasus pada tahun 2017 dan 69 kasus di tahun 2018. Kelurahan dengan kasus diare tertinggi yaitu Kelurahan Jabungan. Pemakaian air yang tidak bersih seringkali menjadi penyebab utama terjadinya diare.

Kelurahan Jabungan merupakan salah satu kelurahan yang ada di Kecamatan Banyumanik Kota Semarang. Luas wilayah Kelurahan Jabungan sekitar $2.265 \mathrm{~km}^{2}$ merupakan wilayah binaan dan penghijauan. Pada Kelurahan Jabungan warganya sebanyak $20 \%$ menggunakan sarana air bersih sumur gali, sebanyak $60 \%$ menggunakan air sumur artesis dan $20 \%$ lainnya menggunakan sumber air dari sendang dan atau PAM.

Kelurahan Jabungan memiliki karakteristik spasial antara daerah yang bervariasi. Penggunaan Sistem Informasi Geografis (SIG) dalam bidang kesehatan masyarakat akan sangat bermanfaat dan mempermudah dalam kegiatan pemantauan aspek keruangan dan upaya pengontrolan yang dapat 
disajikan melalui peta. Selain itu, belum pernah dilakukan analisis spasial untuk melihat tingkat kerentanan diare dengan kondisi sumur gali yang dimiliki oleh warga di Kelurahan Jabungan. Tujuan dari penelitian ini yaitu menganalisis secara spasial kejadian diare dengan keberadaan sumur gali di Kelurahan Jabungan Kota Semarang.

\section{MATERI DAN METODE}

Penelitian ini adalah penelitian observasional yang menggunakan analisis spasial dengan pendekatan overlay yaitu menghasilkan layer baru dimana layer tersebut merupakan hasil dari kombinasi minimal dua layer yang menjadi masukkannya. Populasi dalam penelitian ini yaitu seluruh sumur gali dan masyarakat yang terkena diare yang ada di Kelurahan Jabungan yang berjumlah 31 sumur dan 20 warga. Pengambilan sampel dengan metode total sampling yaitu teknik penentuan sampel bila semua anggota populasi digunakan sebagai sampel. Variabel terikat dalam penelitian ini adalah kejadian diare sedangkan variabel bebasnya adalah kondisi bakteriologis air sumur, jarak sumur dengan jamban serta jarak sumur dengan septictank. Data penelitian dianalisis secara deskriptif dan spasial yang dilakukan dengan menggunakan Sistem Informasi Geografis.

Sistem Informasi Geografis merupakan perangkat lunak yang digunakan untuk menganalisis data spasial dan dapat membuat peta mmenjadi objek yang dinamis. SIG dapat digunakan untuk membantu penelitian kesehatan sebagai upaya pengendalian dan pencegahan penyakit dan epidemi. ${ }^{7}$ Analisis spasial, terdiri dari analisis peta dan analisis pola. Analisis peta (overlay dan buffering) dilakukan pada wilayah tempat tinggal penderita diare dan pemilik sumur gali. Overlay spasial, dikerjakan dengan melakukan operasi join dan menampilkan secara bersama sekumpulan data yang berada di area yang sama. Analisa buffer, digunakan untuk mengidentifikasi area sekitar. Proses mengenerate sekitar lingkaran buffer yang ada fitur-fitur geografi dan kemudian mengidentifikasi apakah berada di luar atau di dalam buffer.

\section{HASIL DAN PEMBAHASAN}

1. Gambaran Lokasi Penelitian

Kelurahan Jabungan termasuk dalam wilayah administratrif Kecamatan Banyumanik Kota Semarang yang terbagi menjadi 6 RW dengan pembagian wilayah seperti pada gambar 1. Lokasi Kelurahan Jabungan berada di pinggir wilayah Kecamatan Banyumanik dengan jarak dari pusat pemerintahan kecamatan yaitu $5 \mathrm{~km}$. Sarana penyedia air bersih yang dimiliki oleh masyarakat Kelurahan Jabungan Kecamatan Banyumanik Kota Semarang terdapat 342 sarana yang terdiri atas sumur bor $(87,72 \%)$, sumur gali $(9,36 \%)$, tangki air bersih $(0,88)$, mata air $(1,75)$ dan bangunan pengolah air $(0,29 \%)$.

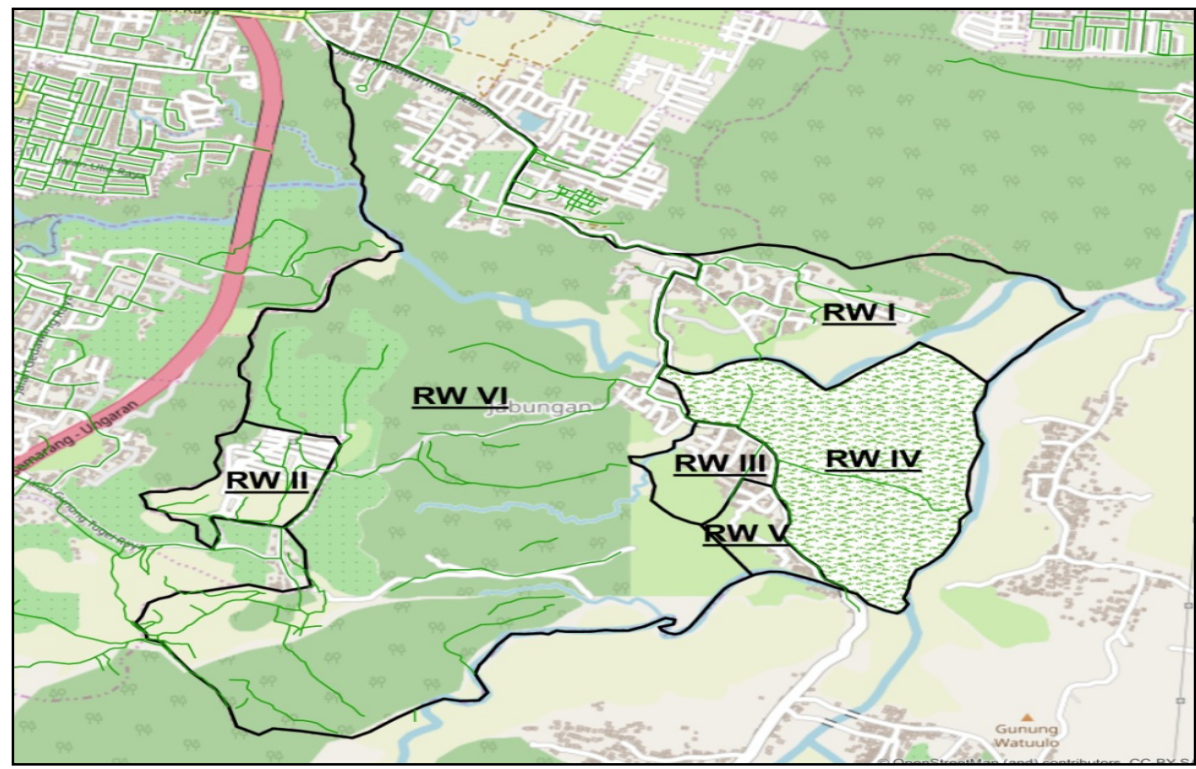

Gambar 1 Lokasi Penelitian Kelurahan Jabungan Kota Semarang

Berdasarkan wawancara dengan pihak petugas Gasurkes dan perangkat Kelurahan Jabungan, RW IV merupakan daerah dengan pelaporan kasus diare terbanyak dibandingankan dengan dengan jumlah kasus 20 orang selama satu tahun terakhir yang didukung dengan data dari Puskesmas Padangsari. Menurut keterangan dari petugas kesehatan Kelurahan Jabungan kebanyakan dari masyarakat Jabungan tidak memeriksakan langsung ke Puskesmas atau Rumah
Sakit terdekat dikarenakan akses jalan yang jauh sehingga perlu adanya pengecekan oleh petugas kesehatan kelurahan dalam hal ini diwakili oleh Gasurkes, kader dan Bidan yang bertugas.

Pengukuran titik koordinat rumah penderita diare dengan menggunakan GPS Garmin 78 dilakukan untuk mengetahui persebaran kejadian diare di RW tersebut. Persebaran kejadian diare di RW IV Kelurahan Jabungan dapat dilihat dari titik-titik kasus 
(dot kasus) yang tersebar di lokasi tersebut. Setiap satu titik kasus, mewakili 1 penderita diare. Dalam gambar 2 menunjukkan bahwa kejadian diare di RW IV cenderung mengelompok di lokasi rumah yang berdekatan.

Kualitas bakteriologis air sumur gali diukur melalui pemeriksaan total coliform dengan menggunakan metode membran filter. Kadar maksimal total coliform yang diperbolehkan pada air bersih adalah $50 \mathrm{CFU} / 100 \mathrm{ml} .^{6}$ Kualitas bakteriologis sumur gali warga RW IV Kelurahan Jabungan dari 31 sumur yang diperiksa sebanyak $87,1 \%$ tidak memenuhi syarat. Meskipun terdapat 4 sumur yang memenuhi syarat sebagai air bersih, namun masih tetap ditemukan total coliform pada air sumur tersebut. Keberadaan total coliform pada sumber air mengindikasikan bahwa air tersebut telah tercemar E.Coli sehingga tidak diperuntukkan sebagai air minum.

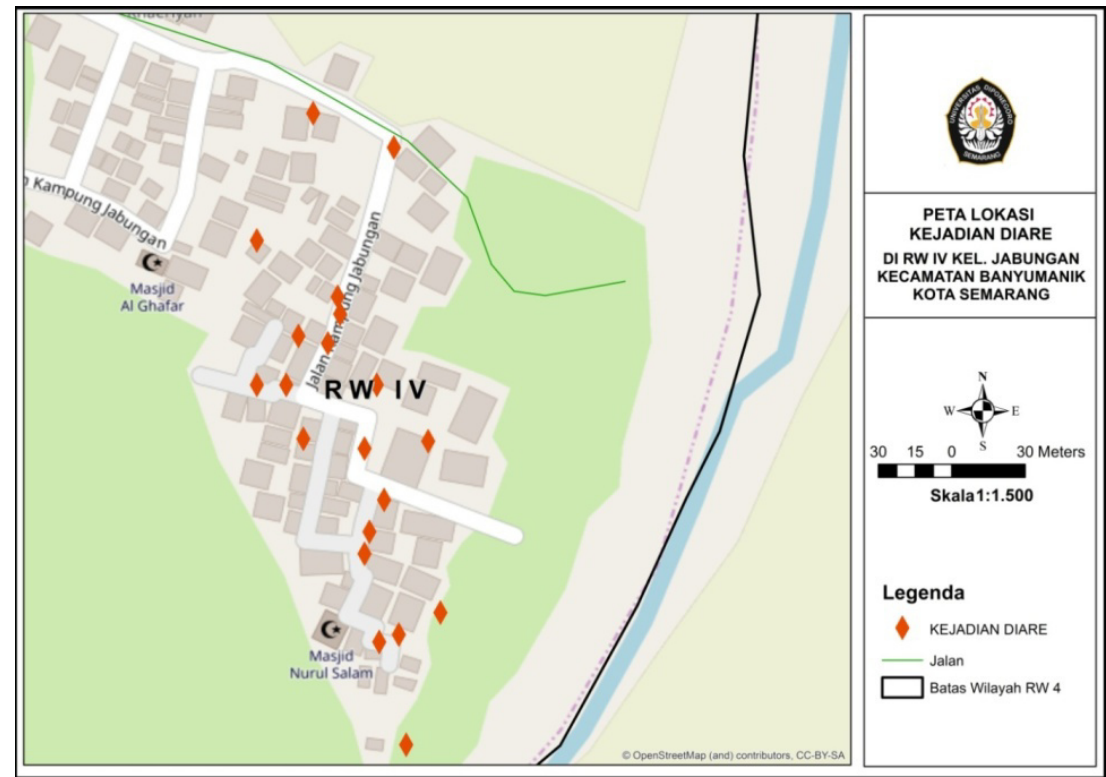

Gambar 2 Sebaran Kejadian Diare di Kelurahan Jabungan tahun 2019

Berdasarkan Peraturan Kemenkes jarak sumur gali dengan sumber pencemar seperti jamban dan septictank adalah berjarak 11 meter. Hasil dari pengukuran jarak antara sumur gali warga dengan jamban diperoleh bahwa hanya terdapat 4 rumah yang keberadaan sumurnya memenuhi syarat yaitu $\geq 11 \mathrm{~m}$ dengan rata-rata jarak sumur gali dengan jamban adalah 7,3 $\mathrm{m}$.

Hasil observasi yang telah dilakukan diperoleh bahwa rata-rata jarak sumur gali dengan septictank adalah $6,9 \mathrm{~m}$. Hasil tersebut menunjukkan bahwa ratarata keberadaan sumur gali yang dimiliki oleh warga tidak sesuai dengan peraturan yang ada yaitu dengan batas minimal jarak sumur dengan septictank. Jarak sumur gali dengan septictank dari 31 sumur yang diobservasi terdapat 27 sumur memiliki jarak yang $<11$ meter, hal tersebut menunjukkan bahwa sebagian besar keberadaan sumur gali yang dimiliki oleh warga tidak memenuhi persyaratan.

2. Analisis Spasial Kualitas Bakteriologis Sumur Gali dengan Kejadian Diare

Hasil pemeriksaan pada air sumur gali menunjukkan bahwa semua air sumur yang diperiksa mengandung bakteri Coliform dan hanya 4 sumur dengan total Coliform yang menunjukkan nilai $\leq 50$ $\mathrm{CFU} / 100 \mathrm{ml}$ yang mengartikan hanya 4 sumur yang memenuhi persyaratan untuk dijadikan sebagai air bersih.

Hasil pemeriksaan tersebut mengindikasikan bahwa air sumur yang ada di Kelurahan Jabungan telah terkontaminasi oleh kotoran manusia atau hewan yang dapat menyebabkan penyakit-penyakit saluran pencernaan seperti diare. Hal ini serupa dengan penelitian yang dilakukan oleh Amadou Toure dkk di Komunitas Pelengana, Segou, Mali yang menghasilkan bahwa sebagian besar sampel air minum di daerah tersebut mengandung total Coliform yang dimungkinkan mengandung patogen. ${ }^{7}$

Semua sampel menunjukkan nilai bakteriologis yang melebihi ambang baku mutu air yang diperbolehkan untuk dimanfaatkan sebagai air minum yaitu $0 \mathrm{CFU} / 100 \mathrm{ml}$. Bakteri E.coli merupakan bakteri indikator sanitasi dan juga bersifat pathogen yang sering menyebabkan berbagai penyakit. ${ }^{8}$

Sebaran kejadian diare di Kelurahan Jabungan banyak ditemukan pada rumah yang memiliki sumur gali dengan kualitas bakteriologis yang tidak memenuhi persyaratan untuk dijadikan sebagai air bersih. Kejadian diare cenderung mengelompok di lokasi rumah yang berdekatan. Dengan melihat sebaran kejadian diare dengan kualitas bakteriologis sumur gali, menunjukkan bahwa adanya keterkaitan antara keduanya, dimana apabila kualitas bakteriologis sumur gali warga tidak memenuhi syarat 
maka dapat meningkatkan peluang terjadinya kasus diare di rumah yang memiliki kondisi sumur gali tersebut.

Kegiatan yang perlu dilakukan adalah mengidentifikasi sumber kontaminasi mikrobiologis dengan mempertimbangkan karakteristik hidrogeologis dari lokasi pengambilan sampel. Dengan dilakukan kegiatan identifikasi di sumber kontaminasi, diharapkan dapat menemukan solusi yang paling benar dan tepat untuk menyelesaikan permasalahan kualitas air yang ada di daerah ini.

3. Analisis Spasial Jarak antara Sumur Gali dan Jamban dengan Kejadian Diare

Sumur gali menyediakan air yang berasal dari lapisan tanah yang relatif dekat dengan permukaan tanah, oleh karena itu mudah terkena kontaminasi melalui rembesan yang berasal dari kotoran manusia, hewan, maupun sisa aktifitas keperluan domestik rumah tangga. Sumur gali sebagai sumber air bersih harus ditunjang dengan syarat konstruksi, syarat lokasi untuk dibangunnya sebuah sumur gali, hal ini diperlukan agar kualitas air sumur gali aman sesuai dengan aturan yang ditetapkan. ${ }^{9}$

Pencegahan pencemaran sumur gali oleh bakteri coliform yang harus diperhatikan adalah jarak sumur dengan jamban, septictank dan sumber-sumber pencemar lainnya. Jarak yang aman antara sumur dengan sumur pencemar seperti jamban adalah tidak kurang dari 11 meter dan diusahakan agar letaknya tidak berada di bawah tempat sumber pencemar tersebut. Adanya jarak antara sumur gali dengan jamban adalah $>11$ meter bertujuan untuk mencegah bakteri yang terbawa oleh air masuk ke dalam air sumur gali.

Keberadaan jamban dengan sumur yang jaraknya masih berada dalam kurang dari radius 11 meter dapat mempermudah adanya pencemaran coliform terhadap sumber air tanah. Jarak jamban yang berdekatan dengan sumur gali dapat mencemari air sumur dengan Escherichia coli. Faktor yang dapat mempengaruhi pencemaran tersebut adalah dikarenakan luas lahan yang terbatas dan bangunan jamban yang tidak kedap air serta porositas dan permeabilitas tanah yang dapat mempengaruhi laju infiltrasi air sehingga dapat mempengaruhi penyerapan bakteri tersebut. ${ }^{10}$

Dalam gambar 3 menunjukkan bahwa kejadian diare cenderung mengelompok di lokasi rumah yang berdekatan dan banyak ditemukan pada rumah yang memiliki sumur gali dengan jarak antara sumur dan jamban tidak memenuhi persyaratan yaitu kurang dari 11 meter. Hal ini diasumsikan bahwa sudah banyak sumur gali warga yang jaraknya dengan jamban kurang dari 11 meter terkontaminasi bakteri Escherichia coli yang dapat menyebabkan pemilik dan pengguna sumur gali tersebut terkena diare.

Kualitas bakteriologis air sangat dipengaruhi oleh jarak sumber air dengan sumber pencemaran, karena kemampuan bakteri bergerak dalam sehari untuk mencapai sumber air menentukan kehidupan bakteri. Bakteri yang dapat mencapai sumber air sebelum batas waktu hidup bakteri, dapat mempengaruhi kualitas air. Keadaan ini dapat menularkan diare melalui media air, atau media makanan yang terkontaminasi oleh E.coli, Entamoeba hystolitica, Sygella, vibrio cholera, dan lain-lain agent penyebab pennyakit. ${ }^{11}$

4. Analisis Spasial Jarak antara Sumur Gali dan Septictank dengan Kejadian Diare

Sistem septictank (SST) paling banyak digunakan sebagai sistem dalam pengumpulan dan pembuangan air limbah rumah tangga di seluruh diunia termasuk di Indonesia yang penggunaannya sangat umum di daerah pedesaan. ${ }^{13}$ Sistem SST dapat menimbulkan potensi pencemaran yang berdampak pada kesehatan manusia dan ekosistem apabila mengenai air tanah. ${ }^{14}$ Pemerintah Indonesia dalam SNI 03-2916-1992 menetapkan jarak hulu dari aliran air tanah atau sumber pengotor (bidang resapan/septic tank) adalah $>11$ meter. ${ }^{15}$

Septictank merupakan satu kompartemen yang biasanya ditempatkan di halaman belakang rumah atau di bagian belakang dalam rumah yang dibuat dari pasangan batu bata yang diplester sebagai dindingnya dan bagian dasarnya tidak dilapisi pasangan bata tersebut, hanya menggunakan tanah asli yang dilengkapi dengan pipa udara. ${ }^{16}$ Masyarakat Kelurahan Jabungan masih jarang melakukan pengurasan septictank. Selama ini septictank yang ada dibiarkan begitu saja lalu meresap ke dalam tanah. Sumur gali menyediakan air yang berasal dari lapisan tanah yang relatif dekat dengan permukaan tanah, sehingga mudah terkontaminasi melalui rembesan. ${ }^{16}$ Umumnya rembesan berasal dari tempat buangan kotoran manusia dan hewan serta limbah dari sumur itu sendiri. ${ }^{17}$

Salah satu penyebab tercemarnya sumber air sumur yang digunakan untuk segala macam kebutuhan pembersih dan air minum adalah jaraknya dengan septictank tidak memenuhi syarat-syarat kesehatan seperti yang telah ditentukan. Jarak septictank yang dimaksud adalah jarak terdekat antara septictank dengan sumur gali yang dinyatakan dalam satuan meter. Hasil pengukuran jarak antara sumur gali dengan septictank terdapat 27 sumur $(87,1 \%)$ yang jaraknya kurang dari 11 meter sehingga dapat dikatakan sebagian besar sumur gali yang dimiliki oleh warga tidak memenuhi syarat keberadaannya. Dari hasil observasi, jarak antara septictank dengan sumur gali yang tidak memenuhi syarat disebabkan karena luas lahan yang terbatas sehingga jarak antara septictank dengan sumur gali berdekatan dan tidak memenuhi standar.

Jarak sumur gali dengan septictank yang terlalu dekat dapat meningkatkan risiko tercemarnya air sumur oleh mikrobiologi yang berasal dari septictank tersebut yang dapat menimbulkan beberapa penyakit seperti diare. Dalam gambar 4.7 dapat 
memperlihatkan bahwa kejadian diare banyak terjadi pada rumah yang memiliki dan menggunakan air sumur gali yang jaraknya berdekatan dengan septictank $(<11$ meter $)$. Hal tersebut dapat diasumsikan bahwa sumur gali warga sudah tercemar bakteri penyebab diare yang dapat dikarenakan jaraknya yang berdekatan dengan sumber pencemar seperti septictank.

Dalam penelitian sebelumnya, ditemukan nilai OR 15,9 sehingga menunjukkan bahwa sumur yang jarak septictank $<11 \mathrm{~m}$ mempunyai resiko tercemar bakteri E. coli 15,9 kali lebih besar dibandingkan sumur yang jarak septictank $\leq 11 \mathrm{~m}$ yang dapat meningkatkan peluang terjadinya kasus diare di daerah tersebut. Hasil uji statistik dalam penelitian tersebut didapatkan $p$ value sebesar 0,003 yang artinya bahwa pada tingkat $(\alpha) 5 \%$, ada pengaruh jarak septictank terhadap jumlah $E$. coli pada sumur gali. $^{12}$

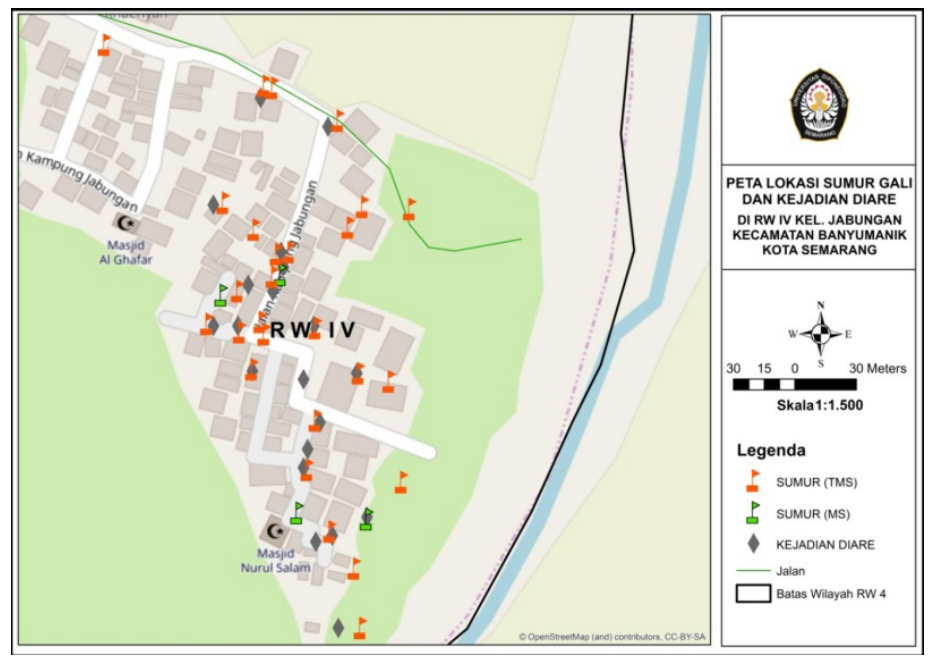

Gambar 3 Sebaran Kondisi Sumur Gali dengan Kejadian Diare di Kelurahan Jabungan tahun 2019

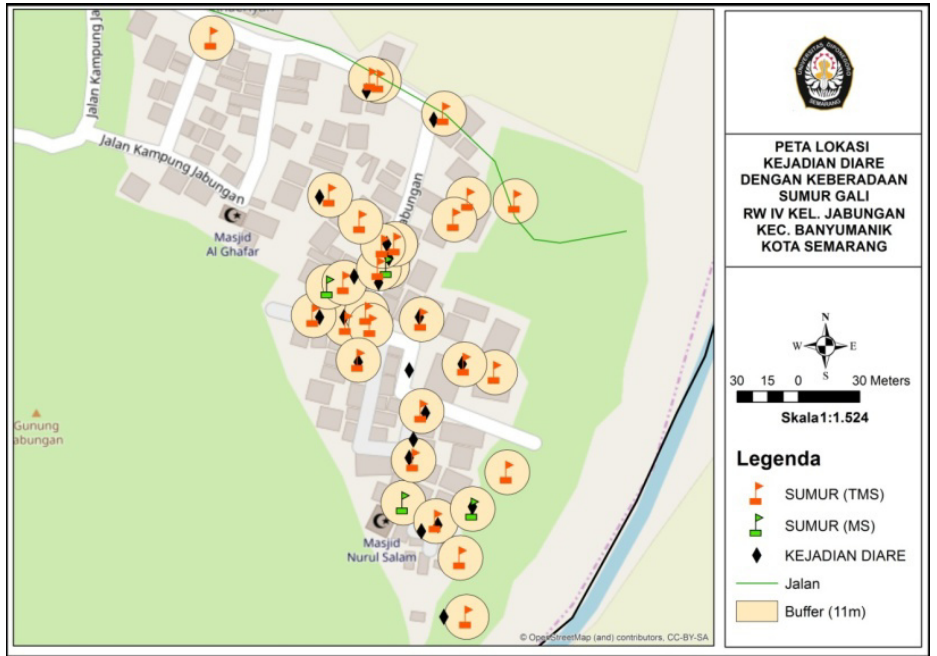

Gambar 4 Sebaran Kejadian Diare dengan Jarak antara Sumur Gali di RW IV Kelurahan Jabungan tahun 2019

Menurut Sri Y. Irda Sari dkk pencemaran yang terjadi pada sumur gali milik masyarakat dikaitkan dengan buruknya kebersihan dan sanitasi karena sejumlah kecil rumah tangga yang menggunakan septic tank. Masyarakat terbiasa membuang limbah manusia langsung ke tepi sungai dengan menggunakan pipa baik yang tertutup maupun terbuka. Pembuangan tinja yang aman juga penting sebagai penghalang pertama untuk penularan penyakit. Oleh karena itu, pengurangan morbiditas dan mortalitas dari penyakit diare memerlukan peningkatan kualitas dan ketersediaan air, pembuangan tinja, dan kebersihan pribadi dan lingkungan secara umum. ${ }^{13}$

\section{Analisis Buffering Jarak antar Sumur Gali}

Penelitian ini juga membahas mengenai jarak sumur gali antar warga di RW IV Kelurahan Jabungan. Kawasan penelitian yaitu di RW IV Kelurahan Jabungan, masyarakatnya memiliki sumber air bersih yaitu sumur gali yang jaraknya cukup berdekatan dikarenakan luas wilayah yang memang sempit untuk dijadikan permukiman. Sebagian besar wilayah RW IV Kelurahan Jabungan masih berupa tebing, sungai 
dan sawah. Hal tersebut menyebabkan warga membangun rumah secara berdekatan.

Memiliki jarak sumur yang berdekatan antar rumah dapat menyebabkan air sumur saling terkontaminasi. Selain dari jarak sumur yang berdekatan antar rumah, kontaminan lain seperti kotoran, jamban, septictank yang memiliki jarak yang berdekatan dengan sumur dapat juga menjadi penyebab terjadinya penyaluran bakteri penyebab penyakit diare. Jarak antar rumah warga di Kelurahan Jabungan rata-rata tidak lebih dari 5 meter. Kualitas air sumur dengan jarak sumur yang berdekatan memiliki karakteristik yang sama. Seperti yang terlihat pada gambar 4 kejadian diare sebagian besar terjadi pada warga yang memiliki sumur dengan jarak berdekatan satu sama lain dengan warga lain yang memiliki sumur tidak memenuhi syarat kualitas bakteriologis.

\section{Analisis Overlay Kondisi Sumur Gali dengan} Kejadian Diare

Berdasarkan analisis overlay, sebaran kejadian diare dengan kondisi sumur gali di RW IV Kelurahan Jabungan mempunyai pola yang mengelompok dengan jarak rumah yang berdekatan. Dengan melihat sebaran kejadian diare dengan kondisi sumur gali menunjukkan bahwa adanya keterkaitan antara keduanya, dimana apabila kondisi sumur gali dalam hal kualitas bakteriologis dan jaraknya dengan sumber pencemar tidak memenuhi syarat maka dapat meningkatkan peluang terjadinya kasus diare di rumah yang memiliki kondisi sumur gali tersebut.

Adanya hal tersebut, memudahkan peneliti atau petugas kesehatan atau pemerintahan Kelurahan untuk melakukan pencegahan (intervensi) berupa edukasi dan promosi yang terkait dengan pengelolaan air bersih tertutama sumur gali dari segi lingkungan dan dampaknya bagi kesehatan. Hal tersebut dapat dilakukan dengan menyisipkan norma, kebiasaan dan budaya yang ada untuk mendorong terjadinya inervensi tersebut. Seperti halnya melakukan kerja bakti setiap minggunya di sumur warga masingmasing yang dibarengi dengan pemeriksaan secara berkala oleh petugas kesehatan setempat untuk menanggulangi penyakit diare. Juga dapat dilakukan pemeriksaan sampel air sumur setiap 6 bulan sekali dengan dikoordinasikan pejabat Kelurahan menggunakan dana desa yang dikumpulkan secara suka rela oleh masyarakat setiap minggunya.

Pada gambar 5 dapat dilihat bahwa daerah yang terdapat kejadian diare dengan kondisi sumur yang buruk (jarak dengan jamban, jarak dengan septic tank, kondisi SPAL, dan kualitas bakteriologis) yang tidak memenuhi syarat, memiliki warna yang semakin gelap dengan persebaran pola mengelompok pada satu daerah. Jika warnanya terang, menunjukkan bahwa daerah tersebut tidak ada kasus diare dan tidak terdapat sumur gali. Dan jika warnanya sedang atau tidak terlalu gelap, menunjukkan bahwa daerah tersebut terdapat kasus yang lebih sedikit dan memiliki sumur gali. Untuk warna yang paling terang menandakan bahwa warna tersebut memiliki keterangan tidak ada sumur dan tidak ada kasus diare di daerah tersebut. Sedangkan yang berwarna agak gelap menandakan bahwa warna tersbut memiliki keterangan di daerah tersebut terdapat sumur dengan kriteria tertentu tetapi tidak terdapat kasus diare pada masyarakatnya. Warna yang paling gelap menandakan daerah tersebut terdapat kasus diare dengan adanya sumur yang memiliki kriteria tertentu yang mendukung terjadinya diare seperti jarak jamban, jarak septictank dan kualitas bakteriologis air.

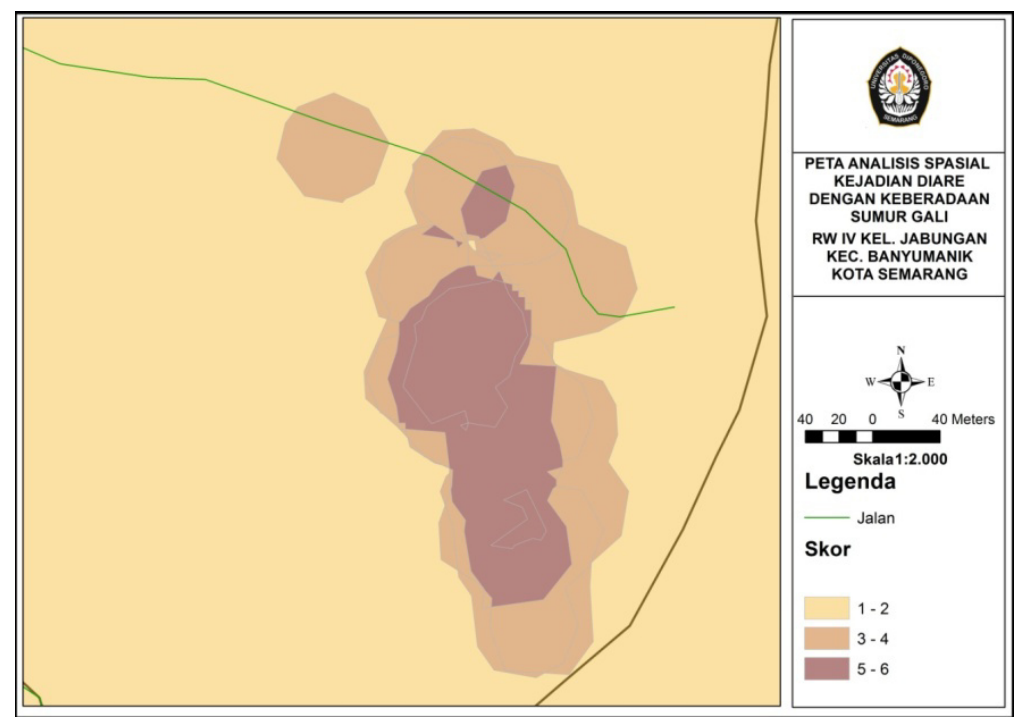

Gambar 5 Sebaran Kejadian Diare dengan Kondisi Sumur Gali di RW IV Kelurahan Jabungan tahun 2019 


\section{SIMPULAN}

Penelitian ini menyimpulkan bahwa sebaran kejadian diare di Kelurahan Jabungan banyak ditemukan pada rumah yang memiliki sumur gali dengan kualitas bakteriologis air yang tidak memenuhi persyaratan yaitu $>50 \mathrm{CFU} / 100 \mathrm{ml}$ sampel dan jarak dengan sumber pencemar yang kurang dari 11 meter. Dengan hal itu maka pihak kelurahan dan petugas kesehatan perlu melakukan pemeriksaan kualitas air sumur gali secara berkala, serta melakukan pengawasan dan pemantauan terhadap kualitas air sumur gali masyarakat tersebut. Selain itu, juga perlu dilakukan penyuluhan secara berkala tentang sanitasi lingkungan dan sarana air bersih khususnya sumur gali kepada masyarakat, serta mengenai upaya perbaikan kualitas air yang tercemar secara bakteriologis seperti pengenalan tentang pembuatan desinfektan secara sederhana seperti klorinasi maupun secara modern.

\section{DAFTAR PUSTAKA}

1. Kementerian Kesehatan RI. Hasil Utama Riskesdas 2018. Jakarta; 2018.

2. Kementerian Kesehatan RI. Profil Kesehatan Indonesia 2016. Kementerian Kesehatan Republik Indonesia. Jakarta; 2016.

3. Dinas Kesehatan Kota Semarang. Profil Kesehatan Kota Semarang 2018. Semarang; 2018.

4. Dinas Kesehatan Provinsi Jawa Tengah. Profil Kesehatan Provinsi Jawa Tengah Tahun 2017. Semarang; 2017.

5. World Health Organization. Making a Difference: Indicators to Improve Children's Environmental Health. Perancis; 2003.

6. Boamah VE, Gbedema SY, Adu F, OforiKwakye K. Microbial quality of household water sources and incidence of Diarrhoea in three PeriUrban communities in Kumasi, Ghana. J Pharm Sci Res. 2011;3(3):1087-92.

7. Ananth M, Rajesh R, Amjith R, Achu AL, Valamparampil MJ, Harikrishnan $\mathrm{M}$, et al. Contamination of Household Open Wells in an Urban Area of Trivandrum, Kerala State, India: A Spatial Analysis of Health Risk Using Geographic Information System. Environ Health Insights. 2018;12:1-9.

8. Kementerian Kesehatan RI. Peraturan Menteri Kesehatan Republik Indonesia Nomor 32 Tahun 2017 tentang Standar Baku Mutu Kesehatan Lingkungan dan Persyaratan Kesehatan Air untuk Keperluan Higiene Sanitasi, Kolam Renang, Solus per Aqua, dan Pemandian Umum. Jakarta; 2017.

9. Toure A, Wenbiao D, Keita Z, Dembele A, Elzaki EEA. Drinking water quality and risk for human health in Pelengana commune, Segou, Mali. J Water Health. 2019;17(4):609-21.

10. Tryland I, Eregno FE, Braathen H, Khalaf G, Sjølander I. On-Line Monitoring of Escherichia coli in Raw Water at Oset Drinking Water Treatment Plant, Oslo (Norway ). 2015;1788802.

11. Sapulette JR, Talarima B, Souisa GV. Gambaran Konstruksi Sumur Gali dan Jarak Septic Tank terhadap Kandungan Bakteri E. Coli pada Sumur Gali. 2-TRIK Tunas-Tunas Ris Kesehat. 2018;8(1):20-8.

12. Nazar H, Kasry A, Saam Z. Perumahan Sederhana di Kota Pekanbaru (Kasus di Kecamatan Tampan). J Ilmu Lingkung. 2010;1(4):63-80.

13. Zulkifli A, Rahmat KB, Ruhban A. Analisis Hubungan Kualitas Air Minum dan Kejadian Diare di Wawondula sebagai Wilayah Pemberdayaan PT. Vale Sorowako. :50-8.

14. Richards S, Paterson E, Withers PJA, Stutter M. Septic tank discharges as multi-pollutant hotspots in catchments. Sci Total Environ. 2016;542:854-63.

15. Withers PJ, Jordan P, May L, Jarvie HP, Deal NE. Do septic tank systems pose a hidden threat to water quality?. Frontiers in Ecology and the Environment. 2013 p. 123-30.

16. Badan Standardisasi Nasional. SNI 03-29161992. Jakarta: Badan Standardisasi Nasional; 1992.

17. Deby P, Andarani P, Sudarno. Pengaruh sistem pengelolaan air limbah domestik terhadap kualitas air sumur ditinjau dari konsentrasi TDS, nitrat, klorida, COD dan total coliform (studi kasus: Rt 03, Rw 01, Kelurahan Kramas, Kecamatan tembalang). J Tek Lingkung. 2016;5(1):1-10.

18. Simanullang TH, Nanda M. Hubungan konstruksi sumur gali dan kandungan coliform pada air sumur terhadap kejadian diare di Desa Ujung Teran Kecamatan Salapian Kabupaten Langkat tahun 2015. JUMANTIK. 2018;3(1):16-28.

19. Muchlis, Thamrin, Siregar SH. Analisis Faktor yang Mempengaruhi Jumlah Bakteri Escherichia coli pada Sumur Gali Penderita Diare di Kelurahan Sidomulyo Barat Kota Pekanbaru. Din Lingkung Indones. 2017;4(1):18-28.

20. Sari SYI, Sunjaya DK, Shimizu-furusawa H, Watanabe C, Raksanagara AS. Water Sources Quality in Urban Slum Settlement along the Contaminated River Basin in Indonesia : Application of Quantitative Microbial Risk Assessment. 2018;2018:1-7. 